\title{
The Application of Farmers Training Model for Sustainable Farming Agriculture During Covid 19 Pandemic
}

\author{
Faizal Amir ${ }^{1}$, Muhammad Ardi ${ }^{2}$, Bakhrani Abdul Rauf ${ }^{2}$, Haruna Haji Latang ${ }^{1}$, Alimuddin Sa'ban Miru ${ }^{3}$, \\ Yasdin $^{1}$, Mthen Lullulangi ${ }^{2}$ * \\ ${ }^{1}$ Department of Automotive Engineering Education, Faculty of Engineering, Universitas Negeri, Makassar, Indonesia \\ ${ }^{2}$ Department of Civil Engineering and Planning Education, Faculty of Engineering, Universitas Negeri, Makassar, Indonesia \\ ${ }^{3}$ Department of Electrical Engineering Education, Faculty of Engineering, Universitas Negeri, Makassar, Indonesia
}

\section{Email address:}

fazialamir64@unm.ac.id (F. Amir), m.ardi@unm.ac.id (M. Ardi), bakhrani@unm.ac.id (B. A. Rauf), haruna@unm.ac.id (Haruna H), alimuddin.smiru@unm.ac.id (Latang),mithen@unm.ac.id (M. Lullulangi)

${ }^{*}$ Corresponding author

\section{To cite this article:}

Faizal Amir, Muhammad Ardi, Bakhrani Abdul Rauf, Haruna Haji Latang, Alimuddin Sa'ban Miru, Yasdin, Mthen Lullulangi. The Application of Farmers Training Model for Sustainable Farming Agriculture During Covid 19 Pandemic. International Journal of Environmental Protection and Policy. Vol. 8, No. 6, 2020, pp. 117-122. doi: 10.11648/j.ijepp.20200806.12

Received: November 9, 2020; Accepted: November 25, 2020; Published: December 8, 2020

\begin{abstract}
The objectives of this research are as follows: (1) to know the knowledge, attitudes, motivation, and behavior of farmers to keep away from the Corona Virus, increase income and environmental quality in technical irrigation areas before and after being trained on: how to keep away from the Corona Virus, the ecosystem wet farming areas, conservation, environment, and farming, (2) to know the effects of experiments whose materials are: how to keep away from the Corona Virus, wet farming area ecosystems, conservation, the environment, and farming to increase knowledge, attitudes, motivation, and the behavior of farmers to keep away from the Corona Virus, increase income, and environmental quality in technical irrigation areas. The research approach is experimental research. The research location was selected by purposive sampling method, namely: Langkemme irrigation area (experimental area) and Saddang irrigation area (control area). There were 25 farmers trained (experimental group) and 25 people (control group). The research variables were: (1) knowledge, attitude, motivation, and keep away from the corona virus before and after the experiment, (2) the effect of the experiment on increasing knowledge, attitudes, motivation, and keep away from the corona virus, increasing income, and environmental quality in the technical irrigation area. The analysis used in this research was descriptive statistical analysis and inferential statistical analysis. The inferential model is the independent $t$ test. The results of the research showed that as follows: (1) knowledge, attitudes, motivation, and behavior of farmers to keep away from the corona virus, increase income, and the quality of the environment in the technical irrigation area before being trained are in the low category, (2) knowledge, attitude, motivation, and the behavior of farmers to keep away from the corona virus, increase income, and the quality of the environment in technical irrigation areas after being trained are in the high category, (3) the effect of training (experimentation) is very positive on increasing knowledge, attitudes, motivation, and keep away of farmers' behavior themselves from the Corona Virus, increasing income and environmental quality in technical irrigation areas.
\end{abstract}

Keywords: Model, Farmer Development, Farming, Technical Irrigation, and Corona Virus

\section{Introduction}

The Law of the Republic of Indonesia Number 32 of 2009 states that the environment needs to be preserved so that it benefits for humans [1]. Faizal Amir (2017) states that technical irrigation areas are built environment for farmers in which there are weirs, primary and secondary channels [2]. The technical irrigation area is a very large value state investment. Therefore, this area needs to be cared by the farmers, so that it will provide the greatest possible benefit for farmers and other communities in the sustainable in the future. 
The Corona virus is a disease that farmers need to be aware in farming. So that farmers can improve the quality of the environment in irrigated areas, increase income, and avoid the Corona Virus, they need knowledge of ecosystems, conservation, the environment, how to avoid the Corona Virus, and farming. Suriasumantri (2010) states that knowledge is essentially all what we know about a particular object obtained through experience and scientific reasoning [3]. Knowledge can shape attitudes, motivation, and behavior (Swan and Stapp in Faizal Amir (2018) [4].

Faizal Amir (2017) has found a training model and teaching materials that can be trained by farmers in increasing income and environmental quality. In addition, the Corona Virus can threaten farmers in farming [2]. For this reason, materials on ecosystems, conservation, farming, the environment, and how to avoid the Corona Virus need to be trained to the farmers, so that they can keep away from the Corona Virus, increase income, and the quality of the environment in irrigation areas.

The objectives of this research are to: (1) find out the knowledge, attitudes, motivation and behavior of farmers to keep away from the Corona Virus, increase income and environmental quality in technical irrigation areas before and after being trained on: how to avoid the Corona Virus, regional ecosystems, wet agriculture, conservation, the environment, and farming, (2) to know the effects of experiments that materials are: how to keep away from the Corona Virus, wet agricultural area, ecosystems, conservation, the environment, and farming to increase knowledge, attitudes, motivation, and the behavior of farmers to keep away from the Corona Virus, increase income, and environmental quality in technical irrigation areas.

The theories that support this research are described as follows. Hanrahmawan (2010) and Sanjaya (2011) state that the development of a training model through a cycle of activities starts from: analyzing training needs; designing a training approach; training material development; implementation of training; evaluation and improvement of training [5, 6]. Sanjaya (2011), designed a training model starting from: identifying objectives, formulating tests, developing learning strategies, and conducting evaluations [6].

The Law of the Republic of Indonesia Number 32 of 2009 [1] states that the environment is a system which is a spatial unit with all objects, conditions, and living things including humans and their behavior which determines the life and welfare of humans and other living creatures. Faizal Amir (2018) said that the essence of environmental management by humans is how human makes efforts to improve human quality, while environmental quality is also getting better [4].

Laycock (2007) states that the purpose of irrigation development is to get water needs for agricultural purposes, for soil cultivation, fertilization, soil temperature control, and pest control [7]. Ansori (2018) states that irrigation networks in Indonesia are divided into three categories, namely (1) technical irrigation, (2) semi-technical irrigation, and (3) simple irrigation [8]. Mawardi (2010) states that the principles of technical irrigation networks are as follows: (1) getting a separate water supply from the waster network, (2) providing water can be measured and regulated, (3) tertiary plots becomes a central function, ( 4) all buildings are permanent [9].

Suriasumantri (2010) states that knowledge is all we know about a particular object [3]. Bloom in Faizal Amir (2018) states that the better knowledge will have an impact on increasing attitudes, motivation, and behavior [4]. Suriasumantri (2010) states that knowledge consists of three components, namely: cognitive, affective, and psychomotor [3].

Azwar (2013) states that attitude is a person's evaluative response or response to the environment. Attitude consists of three components, namely affection, cognition, and conation [10]. Vivas (2010) states that attitude is an evaluation or human response to environmental stimuli [11]. Azwar (2013) states that attitudes are formed by the presence of knowledge, experience, and one's sense of attitude objects [10]. Furthermore, Azwar (2013) states that: (1) the cognitive component contains a person's belief about what applied and is true for the object of attitude, (2) the affective component concerns a person's emotional problems with an object of attitude, and (3) the component co native is the tendency to behave towards the object of attitude [10].

Adnil (2011) explains that motivation is a force that exists in a person that can encourage, move, and direct one's behavior [12]. Furthermore, it is said that motivation consists of two parts, namely motivation that comes from within humans (intrinsic) and motivation that comes from outside the human self (extrinsic). Sarwono in Faizal Amir, 2018) states that motivation arises because of human needs or desire to be fulfilled [4].

Swan and Stapp in Faizal Amir (2018) state that behavior is a series of actions built by knowledge, filing, values and attitudes [4]. Jiang. (2012) stated that behavior is an individual act or reflection caused by psychological aspects, such as knowledge, perception, intention, desire and attitude [13]. Tukiyat (2009) states that behavior is the result of an act of someone who is carried out continuously and has trends that are continuously carried out in the situation and conditions faced [14]. Hungerford and Volk (1991) state that environmental behavior is influenced by several factors, including knowledge, attitudes, motivation, locus of control and so on [15]. Mankiw (2011) states that revenue is the result of multiplying the number of units sold and the price per unit [16].

\section{Research Methods}

The type of this research is experimental research. The research location is the Langkemme irrigation area of Soppeng Regency and Saddang irrigation area in Sidrap Regency which were selected by purposive sampling method. The sample of farmers in the Langkemme irrigation area were 25 farmers as the experimental group and the sample of farmers in the Saddang irrigation area were 25 farmers as the 
control group selected by purposive sampling. Thus the total samples are 50 farmers.

The variables considered in this research are: 1) Knowledge, attitudes, motivation, and behavior of farmers to keep away from the Corona Virus, increase income, and environmental quality in the technical irrigation area before and after being given training. 2) The effect of training on increasing knowledge, attitudes, motivation and behavior of farmers to keep away from the Corona Virus, increase income, and the quality of the environment in technical irrigation areas.

The experimental design used was a pretest-posttest control group design (Borg \& Gall, 2007). [17] The data analysis used was descriptive statistics and infrared statistical analysis. The inferential analysis model is an independent $t$ test.

\section{Research Finding and Discussion}

\subsection{Description of Knowledge}

Description of Farmers' Knowledge to Avoid Corona Virus, Increase Income, and Environmental Quality in Technical Irrigation Areas Prior to Experimentation.

\subsubsection{Experiment Group}

The results of the descriptive statistical analysis of the knowledge of the experimental group farmers about how to keep away from the corona virus, increase income, and the quality of the environment in the technical irrigation area prior to the implementation of the experiment obtained an average value $=5.88$. The maximum value $=9$, and the minimum value $=3$. Based on the frequency distribution, it can be seen that the average value is in the low category. Thus it can be concluded that the knowledge of the experimental group farmers before the experiment was in the low category.

\subsubsection{Control Group}

The results of the descriptive statistical analysis of the knowledge of the control group farmers about how to keep away from the corona virus, increase income, and the quality of the environment in the technical irrigation area before the implementation of the experiment obtained an average value of $=5.64$. The maximum value $=10$, and the minimum value $=3$.

Based on the frequency distribution, it can be seen that the average value is in the low category. Thus it can be concluded that the knowledge of the control group farmers before the experiment was in the low category.

Description of Knowledge Farmers keeping away from Corona Virus, Increasing Income, and Environmental Quality in Technical Irrigation Areas after Experimentation.

\subsubsection{Experiment Group}

The results of the descriptive statistical analysis of the knowledge of the experimental group farmers about how to keep away from the corona virus, increase income, and the quality of the environment in the technical irrigation area after the experiment obtained an average value $=13.48$. The maximum value $=18$, and the minimum value $=9$. Based on the frequency distribution, it can be seen that the average value is in the high category. Thus it can be concluded that the knowledge of the experimental group farmers after implementing the experiment increased, which was in the high category. This increase in knowledge was caused by the seriousness of the farmers in following the experiment. In addition, control is carried out on the effects of testing, maturation effects, and mortality effects.

The results of the descriptive statistical analysis of the knowledge of the control group farmers about how to keep away from the corona virus, increase income, and the quality of the environment in the technical irrigation area after the experiment obtained an average value of $=5.64$. The maximum value $=11$, and the minimum value $=2$. Based on the frequency distribution, it can be seen that the average value is in the low category. Thus it can be concluded that the knowledge of the control group farmers after the implementation of the experiment remains in the low category. This is only natural, because farmers in this group act as controls only or do not get treatment.

\subsection{Attitude Description}

\subsubsection{Description of the Attitude of Farmers to Avoid Corona Virus}

(i) Experiment Group

The results of descriptive statistical analysis of the attitude of the experimental group farmers on how to keep away from the corona virus, increase income, and quality environment in the technical irrigation area before the experiment obtained an average value $=44.8$. The maximum value $=63$, and the minimum value $=25$.

Based on the frequency distribution, the average value is in the negative category. Thus it can be concluded that the attitude before conducting the experiment is in the negative category.

(ii) Control Group

The results of the descriptive statistical analysis of the attitude of the control group farmers on how to keep away from the corona virus, increase income, and the quality of the environment in the technical irrigation area before the experiment obtained an average value $=43.84$. The maximum value $=64$, and the minimum value $=28$. Based on the frequency distribution, the average value is in the negative category. Thus it can be concluded that the attitude of the control group farmers before the experiment was in the negative category.

\subsubsection{Description of the Attitude of Farmers to Keep Away from the Corona Virus}

(i) Experiment Group

The results of descriptive statistical analysis of the attitude of the experimental group farmers on how to keep away from the corona virus, increase income, and the quality of the environment in the technical irrigation area after the experiment obtained an average value $=74.8$. The maximum 
value $=87$, and the minimum value $=41$. Based on the frequency distribution, the average value is in the positive category. Thus it can be concluded that the attitude of the experimental group farmers after the experiment was in the high or positive category. The positive attitude of the farmers was due to the seriousness of participating in the training. In addition, control is carried out on the effects of testing, maturation effects, and mortality effects.

(ii) Control Group

The results of the descriptive statistical analysis of the attitude of the control group farmers on how to keep away from the Corona Virus, increase income, and the quality of the environment in the technical irrigation area after the experiment obtained an average value $=44.12$. The maximum value $=65$, and the minimum value $=28$. Based on the frequency distribution, the average value is in the negative category. Thus it can be concluded that the attitude of the group farmers after the implementation of the experiment is in the negative category. The attitude of the farmers did not change, this is only natural because the control group did not receive training materials.

\subsection{Descriptions of Motivation}

\subsubsection{Description of the Motivation of Farmers to Keep Away from the Corona Virus}

(i) Experiment Group

The results of the descriptive statistical analysis of the motivation of the experimental group farmers to keep away from the Corona Virus, increase their income, and the quality of the environment in the technical irrigation area before the experiment obtained an average value $=45$. The maximum value $=65$, and the minimum value $=30$. Based on the frequency distribution, the average value is in the low category. Thus it can be concluded that the motivation of the experimental group farmers before the experiment was in the low category.

(ii) Control Group

The results of descriptive statistical analysis of the motivation of the control group farmers to keep away from the Corona Virus, to increase income, and the quality of the environment in the technical irrigation area before the experiment obtained an average value of $=44.92$. The maximum value $=65$ and the minimum value $=26$. Based on the frequency distribution, the average value is in the low category. Thus it can be concluded that the motivation of the control group farmers before the experiment was in the low category.

\subsubsection{Description of the Motivation of Farmers to Keep Away from the Corona Virus}

(i) Experiment Group

The results of the descriptive statistical analysis of the motivation of the experimental group farmers to keep away from the Corona Virus, to increase their income, and the quality of the environment in the technical irrigation area before the experiment obtained an average value of $=70.2$. The maximum value $=86$ and the minimum value $=54$. Based on the frequency distribution, the average value is in the high category. Thus it can be concluded that the motivation of the experimental group farmers after the experiment was in the high category. Farmers' high motivation was due to the seriousness of participating in the training. In addition, the control is carried out on the effects of testing, maturation effects, and mortality effects.

(ii) Control Group

The results of descriptive statistical analysis of the motivation of the control group farmers to keep away from the Corona Virus, to increase income, and the quality of the environment in the technical irrigation area before the experiment obtained an average value of $=45.24$. The maximum value $=64$ and the minimum value $=27$. Based on the frequency distribution, the average value is in the low category. Thus it can be concluded that the motivation of the control group farmers after the implementation of the experiment is in the low category. Farmers' motivation did not change after the experiment was carried out. This is only natural because the control group did not receive training material.

\subsection{Description of Behavior}

\subsubsection{Description of Farmer Behavior to Keep Away from the Corona Virus}

(i) Experiment Group

The results of descriptive statistical analysis of the behavior of the experimental group farmers to keep away from the Corona Virus, increase their income, and the quality of the environment in the technical irrigation area before the experiment obtained an average value of $=44.4$. The maximum value $=65$, and the minimum value $=30$. Based on the frequency distribution, the average value is in the low category. Thus it can be concluded that the behavior of the experimental group farmers before the experiment was in the low category.

(ii) Control Group

The results of descriptive statistical analysis of the behavior of control group farmers to keep away from the Corona Virus, increase income, and environmental quality in the technical irrigation area before the experiment obtained an average value $=44.48$. The maximum value $=65$ and the minimum value $=31$. Based on the frequency distribution, the average value is in the low category. Thus it can be concluded that the behavior of the control group farmers before the implementation of the experiment was in the low category.

\subsubsection{Description of Farmers' Behavior to Keep Away from the Corona Virus.}

(i) Experiment Group

The results of descriptive statistical analysis of the behavior of the experimental group farmers to keep away from the Corona Virus, increasing their income, and the quality of the environment in the technical irrigation area after the experiment obtained an average value of $=74.4$. The maximum value $=86$ and the minimum value $=55$. Based on 
the frequency distribution, the average value is in the high category. Thus it can be concluded that the behavior of the experimental group farmers increased, namely in the high category. This high farmer behavior is caused by seriousness attend training. In addition, the control is carried out on the effects of testing, maturation effects, and mortality effects.

(ii) Control Group

The results of descriptive statistical analysis of the behavior of control group farmers to keep away from the Corona Virus, increase income, and environmental quality in the technical irrigation area before the experiment obtained an average value of $=44.1$. The maximum value $=65$ and the minimum value $=28$. Based on the frequency distribution, the average value is in the low category. Thus it can be concluded that the behavior of the control group farmers after the experiment remains in the low category. Farmers' behavior did not change after conducting the experiment. This is only natural because the control group did not receive training material.

\subsection{The Effect of Experiments on Increasing Knowledge, Attitudes, Motivation, and Behavior of Farmers}

\subsubsection{Increased Knowledge}

The results of inferential statistical analysis ( $t$ test) in Table 1 show that $\mathrm{t}=0.000<\alpha=0.05$. This means that the implementation of the experiment has an influence on increasing farmers' knowledge about how to keep away from the Corona Virus, increase income, and the quality of the environment in technical irrigation areas. The correlation coefficient $=0.842$ or the coefficient of determination $(R 2)=0.7089$. This figure shows the magnitude of the effect of the experiment implementation is $70.89 \%$. Thus it can be concluded that the implementation of the experiment has a positive effect on increasing farmers' knowledge.

Table 1. The result of the $t$ Test Analysis, The Effect of Experiment Implementation on Increasing Knowledge, Attitudes, Motivation, and Behavior of Farmers to keep away from the Corona Virus, Increase Income, and Environmental Quality in Technical Irrigation Areas.

\begin{tabular}{|c|c|c|c|c|c|c|c|c|}
\hline & \multicolumn{5}{|c|}{ Paired Differences } & \multirow[t]{2}{*}{ t } & \multirow[t]{3}{*}{ df } & \multirow[t]{2}{*}{ Sig. (2 tailed) } \\
\hline & \multirow{2}{*}{ Mean } & \multirow{2}{*}{$\begin{array}{l}\text { Std. } \\
\text { Deviation }\end{array}$} & \multirow{2}{*}{$\begin{array}{l}\text { Std. Error } \\
\text { Mean }\end{array}$} & \multicolumn{2}{|c|}{ 95\% Confidence Interval of the Difference } & & & \\
\hline & & & & Lower & Upper & & & \\
\hline Knowledge: $\mathrm{R}=0.842$ & 7.6 & 1.73 & 0.34 & 8.31 & 6.88 & 21.93 & 24 & .000 \\
\hline Attitude $\mathrm{R}=0.837$ & 21 & 6.95 & 1.39 & 23.87 & 18.12 & 15.09 & 24 & .000 \\
\hline Motivation: $\mathrm{R}=0.857$ & 18,8 & 7.21 & 1.44 & 21.77 & 19.82 & 13.02 & 24 & .000 \\
\hline Behavior: $\mathrm{R}=0.774$ & 20,08 & 8.9 & 1.78 & 23.74 & 16.465 & 11.27 & 24 & .000 \\
\hline
\end{tabular}

\subsubsection{Attitude Improvement}

The results of inferential statistical analysis ( $t$ test) in Table 1 show that $\mathrm{t}=0.000<\alpha=0.05$. This means that the implementation of the experiment has an effect on increasing the attitude of farmers to keep away from the corona virus, increase income and environmental quality in technical irrigation areas. The correlation coefficient $=0.837$ or the coefficient of determination $(\mathrm{R} 2)=0.7005$. This figure showed that the magnitude of the effect of implementing the experiment on increasing farmer attitudes is $70.05 \%$. Thus it can be concluded that the implementation of the experiment has a positive effect on increasing farmer attitudes.

\subsubsection{Increased Motivation}

The results of inferential statistical analysis ( $t$ test) in Table 1 show that $\mathrm{t}=0.000<\alpha=0.05$. This means that the implementation of the experiment has an effect on increasing the motivation of farmers to keep away from the corona virus, increase income, and the quality of the environment in technical irrigation areas. The correlation coefficient $=0.857$ or the coefficient of determination $(\mathrm{R} 2)=0.7344$. This figure showed that the magnitude of the effect of the experiment implementation on increasing farmer motivation is $73.44 \%$. Thus it can be concluded that the implementation of the experiment has a positive effect on increasing farmer motivation.

\subsubsection{Behavior Improvement}

The results of inferential statistical analysis ( $t$ test) in Table
1 showed that the significant $\mathrm{t}=0.000<\alpha=0.05$. This means that the implementation of the experiment has an influence on increasing the behavior of farmers to keep away from the corona virus, increase income, and the quality of the environment in technical irrigation areas. Correlation coefficient $(R)=0.774$; or the coefficient of determination $(R 2)=0.6$. This figure showed that the magnitude of the effect of implementing the experiment on improving farmer behavior is $60 \%$. Thus it can be concluded that the implementation of the experiment has a positive effect on improving farmer behavior.

\section{Conclusion}

Farmers' knowledge about how to avoid the corona virus, increase income, and the quality of the environment in the technical irrigation area before being trained is in the low category, attitudes are in the negative category, motivation is in the low category, and behavior is in the low category.

Farmers' knowledge about how to avoid the corona virus, increase income, and the quality of the environment in technical irrigation areas after being trained is in the high category, attitudes are in the positive category, motivation is in the high category, and behavior is in the high category.

Training materials consisting of: how to avoid the corona virus, the ecosystem of wet farming areas, the environment of wet farming areas, environmental conservation, and farming, have a positive effect on increasing knowledge, attitudes, motivation, and behavior of farmers to avoid 
corona viruses, increasing income, and environmental quality in technical irrigation areas.

\section{Acknowledgements}

Acknowledgments are conveyed to: 1) Ministry of Research and Technology / National Agency for Research and Innovation and the General of Higher Education for funding this research as a form of coaching for lecturers in Higher Education 2) Rector of Makassar State University for his permission, guidance, and motivation so that this research is carried out well. 3) The head of the Institute for Research and Community Services (LP2M) Makassar State, 4) University for his support and direction in conducting this research properly, 5) Soppeng and Sidrap District Governments for their support and granting of permits to conduct the research, 6) Farmers as research respondents for their participation and cooperation, 7) All members of the research team for their good cooperation, and 8) All people who have participated in this research, were not mentioned one by one.

Hopefully what all people and team have done in completing this research can provide the greatest benefit for Makassar State University, Society, Nation and State.

\section{References}

[1] Law of the Republic of Indonesia Number 32 of 2009 concerning Environmental Protection and Management.

[2] Faizal Amir, Haruna HL., dan Saharuna. (2017). Fostering Farmers in Increasing the Income and Quality of the Environment in the Irrigation Area of Textnis Sulawesi Se Equipment. Makassar: UNM Publishing Agency.

[3] Suriasumantri. (2010). Filsafat Ilmu: Sebuah Pengantar Populer. Jakarta: Pustaka Sinar Harapan.

[4] Faizal Amir, Muhamad Ardi., dan Marsus Suti. (2018). Fostering Farmers in Increasing Income and Environmental Quality in a Sustainable Way in the Sulawesi Tenggara Timur Irrigation Area. Edition II. Makassar: UNM Publishing Agency.

[5] Hanrahmawan, Fitroh. (2010). "Revitalization of Manpower
Training Management" (Case Study at the Makassar Industrial Vocational Training Center). Journal of Public Administration. Vol 1. No. 1. 2010.

[6] Sanjaya, Wina. (2011). Educational Process Standards Oriented Learning Strategy. Jakarta: Kencana Prenada Media.

[7] Laycock, Andrian. (2007). Irrigation System Design, Planning and Cons-truction. UK: CABI Head Office Nosworthy Way Wallingford, Oxfordshire.

[8] Ansori, Mohamad Bagus, Edijanto, dan S. R. Soesanto. (2018) Irrigation and Building nair. Srabaya: Sepuluh Nopember Institute of Technology.

[9] Mawardi, Erman. (2010). Irrigation Building Hydraulic Design. Bandung: Alfabeta Publisher.

[10] Azwar, S. (2013). Human Attitudes, Theory and Measurement. Yogyakarta: Student Library Publisher.

[11] Vivas, A., Gelaye, B., Aboset, N., Kumie, A., Berhane, Y., and Williams, M. A. (2010). Knowledge, Attitudes, and Practices (KAP) of Hygiene amongSchool Children in Angolela. EthiopiaPublished in final edited form as: J Prev Med Hyg. $2010 \quad$ June 5 http://www.ncbi.nlm.nih.gov/pmc/articles/PMC3075961/pdf/n ihms-251062.pdf. Diakses 21 Septeber 2017).

[12] Adnil, Edwin Nurdin. (2011). Growth and Development of Human Behavior. Jakarta: Book Medical Publishers EGC.

[13] Jiang, G., Matthew L. Boulton, Zhuo Wang, Jing Li, Wei Li, Dezheng Wang, Hao Liu, Wenlong Zheng, Yi Yang, Gai Chang, Fan Zhang, and JoLinn P. Montgomery. (2012). "Community Intervention Trial Promote Healty Behaviors in Farmers in Tianjin, China. Journal of Behavioral Helath. 1 (2), $77-85$

[14] Tukiyat. (2009). "Situ Rawa Besar Community Behavior in Managing the Environment." Dissertation. Jakarta: Postgraduate Program, State University of Jakarta.

[15] Hungerford, H. R, dan Volk, T. L. (1991). Changing Learner Behavior Trough Environmental Education. Unesco, UNDP, UNICEF, and World Bank. (www.elkhornsloughctp.org. Diakses 29 Maret 2017).

[16] Mankiw, N. G. (2011). Principle of Economic. 6th Edition. Mason: South-Western Change Learning.

[17] Borg \& Gall. (2007). Educational Research: An Introduction, 8th Edition. USA: Pearson. 